The University of Akron

\title{
IdeaExchange@UAkron
}

Proceedings from the Document Academy

University of Akron Press Managed

December 2014

\section{Dutch Landscape Painting: Documenting Globalization and Environmental Imagination}

Irene J. Klaver

University of North Texas, irene.klaver@unt.edu

Please take a moment to share how this work helps you through this survey. Your feedback will be important as we plan further development of our repository.

Follow this and additional works at: https://ideaexchange.uakron.edu/docam

Part of the Dutch Studies Commons, Fine Arts Commons, Other Arts and Humanities

Commons, and the Philosophy Commons

\section{Recommended Citation}

Klaver, Irene J. (2014) "Dutch Landscape Painting: Documenting Globalization and Environmental Imagination,"

Proceedings from the Document Academy: Vol. 1 : Iss. 1 , Article 12.

DOI: https://doi.org/10.35492/docam/1/1/12

Available at: https://ideaexchange.uakron.edu/docam/vol1/iss1/12

This Conference Proceeding is brought to you for free and open access by University of Akron Press Managed at IdeaExchange@UAkron, the institutional repository of The University of Akron in Akron, Ohio, USA. It has been accepted for inclusion in Proceedings from the Document Academy by an authorized administrator of

IdeaExchange@UAkron.For more information, please contact mjon@uakron.edu, uapress@uakron.edu. 


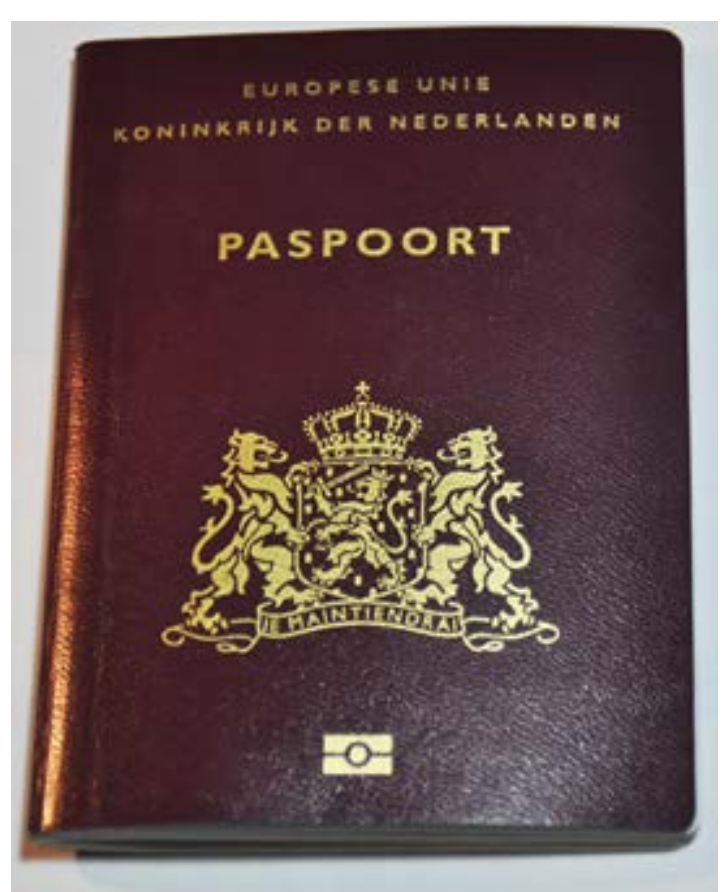

A passport is often considered the defining document of one's nationality. After more than twenty years of living in the United States, I still carry my Dutch passport. It still feels premature for me to give it up and become an American. When people ask, "Where are you from?” I answer, "Denton, Texas." This usually triggers, "OK, but where are you FROM???” It is the accent that apparently documents my otherness. I then say, "Originally I am from the Netherlands." "Oh, OK.” Their first association with this new information will not be my winecolored, maroon Dutch passport, but most likely something like tulips, cheese, windmills, wooden shoes, Van Gogh, Amsterdam liberalism in the use of marihuana, and so forth. This kaleidoscope of images carries more cultural weight towards documenting my national identity than its most official document, the passport. Here I explore some of these images as exemplars of "Documents without Borders" and show how documents keep drawing new borders.

\section{Tulips or the Dutch National Selfie}

The landscape north of Amsterdam is typically Dutch. Black and white milk cows graze peacefully in green pastures interlaced by small ditches; an occasional windmill on the horizon. It is Spring 2012 and I am taking the train to visit my mother in Alkmaar, a town forty kilometers north of Amsterdam, famous for its cheese. I am reading the newspaper and I glance occasionally at the familiar North Holland landscapes. The green polder-pasture landscape turns into another proto-typically Dutch one: vast geometrical tulip fields. 


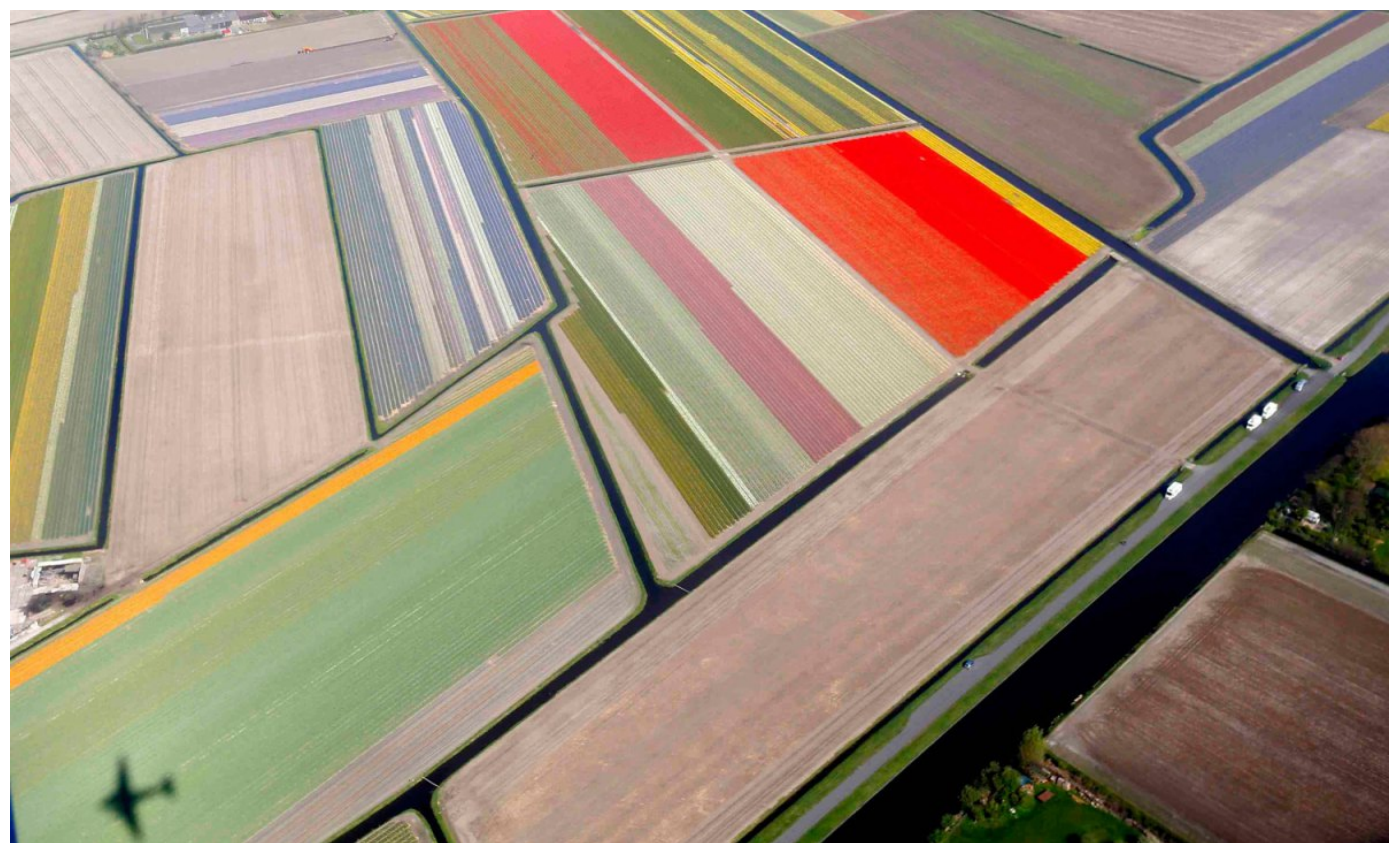

Aerial view of flower fields near the Keukenhof park, also known as the Garden of Europe, in Lisse, Netherlands, on April 9, 2014. Keukenhof is considered to be the world's largest flower garden displaying millions of flowers every year. (Yves Herman-Reuters)

The flowering fields, documenting countless bulbs tucked in the soil, make my mind drift to various places I have lived in the United States: New York City and Long Island; Billings, Montana; Turlock, California; and Denton, Texas. In each of these places people planted Dutch bulbs, bought in local American supermarkets, K-Marts, Safeways, Country Markets, Albertsons, Walmarts. The abundant presence of Dutch bulbs in faraway Billings, always gave me pause. Isn't it too much for a country a tenth the area of Montana with 16 times its population to play such a flower-power role?

Staring out of the train's window, daydreaming about typically Dutch landscapes, it came to mind that tulips were not typical for this particular area of the Netherlands. The tulip fields where I worked during summer vacations years ago - together with other underpaid young teenagers - were closer to the sea, in the sandy lands behind the dunes. This train's route however, is more inland, which is mainly polder land — that is, land reclaimed from water, in this case from lakes, which were pumped dry, yes, with windmills. The soil that surfaced was thick with clay. It is ideal land to grow grass, cabbage, and potatoes, but not good for tulips. The clay turns into stubborn mud after the slightest rain in misty mornings; one actually does need wooden shoes to avoid sinking into it. Tulips don't like it; they came from Turkey; they like loosely structured, well-drained sandy soils; tulips don't care for tenacious clay and wooden shoes. 
The older polders were the domains of black and white milk cows. But in the early 1980s too much cow-milk came to mean mountains of butter, which were shipped away as European Community-surplus to the Russian tundras. In response the European Union introduced milk quotas and it became more profitable to grow flower bulbs. However, in order for the polders to yield bulbs, their clay soils needed to be transformed into sandy soils. By injecting water into a stratum of sand found ten meters under the clay, sandy slurry was sucked up and spouted over the clay surface, turning it into ideal tulip bulb land. Thus one 'typically Dutch' landscape was turned into another 'typically Dutch' landscape. In order to sell bulbs in Billings, Montana, Dutch polder areas were turned around, upside down, and inside out: the soil was adjusted to cater to a globalized economic market. There is a saying that God made the Earth and the Dutch made the Netherlands - by engineering the relationships of the water and the land. The Dutch had changed their soil again, this time to accommodate 'their' tulips.

This was nothing radically new under the Dutch sun. Most land around Alkmaar had been reclaimed from inland lakes and gleaned from the sea during the Dutch Golden Age, an era of unprecedented economic prosperity, roughly spanning late $16^{\text {th }}$ and the $17^{\text {th }}$ century. Great shipbuilders and keen mapmakers, the Dutch had become world leaders in trade, science, industry and arts. The Dutch East India Company had acquired a monopoly on Asian trade and became the first multinational corporation financed by shares of the first modern stock exchange and the Bank of Amsterdam became the first central bank. The Dutch dominated the trade routes between east and west and north and south, between European countries, from the Baltic Sea to the North Sea, from the Mediterranean all the way to the new English colonies in North America. Imported spices, wine, grain, and other goods were sold with tremendous profits. The wealth of these prolific merchants financed the major polder drainage projects. With the water pumped away, fertile clay surfaced, and grain production and dairy farming followed. By comparison, the $20^{\text {th }}$ century's turning of clay into sand was a minor modification.

Each iteration of the soil can be seen as a member of a family of documents. Each iteration of the soil has the capacity to generate a new national selfie in the eyes of the other - a powerful document of identity. Where a passport relates to the simple delineation of territory with its borders, a 'soil document' embodies a cornucopia of potential documents - eg, catalogs of tulip bulbs, landscape paintings, calendar images of windmills, accountants' ledgers and stockholders certificates, et cetera. Soil and landscape are natural as well as cultural phenomena, operating on hydrology, climate, and market mechanisms.

For understanding this complex constellation of documents, Holland, or the Netherlands -both names for the same low lands of the Dutch- offers fertile grounds. Its five-hundred-year history of inventing and reinventing, creating and 
recreating itself had profound impacts on the Dutch social imaginary or cultural imagination, as exemplified in the rise of $17^{\text {th }}$ century landscape painting, pioneered by Dutch painters. The Dutch word for landscape - landschap meant originally 'region' or 'tract of land,' and acquired an additional painterly connotation with the landscape painting genre as 'a picture depicting scenery or land,' 'a painting representing natural scenery.' The suffix -scape (in Dutch, schap) is etymologically rooted in skap, which means to create, ordain, or appoint (see http://www.etymonline.com/). The Dutch verb is scheppen, to make, shape or create, which is clearly a central characteristic of the Dutch landscape. In the saying: "God created the world, but the Dutch created the Netherlands" the word "God” is, in Dutch, the Schepper.

Cultural theorist and anthropologist Arjun Appadurai brings the very suffix -scape to a next level in his cogent analysis of global cultural flows. He speaks of ethnoscapes, mediascapes, technoscapes, financescapes and ideoscapes as the cultural dimensions of globalization, all "deeply perspectival constructs, inflected by the historical, linguistic, and political situatedness" (Appadurai, 323). These landscapes form the building blocks of "imagined worlds" the works of the imaginary, the "constructed landscape of collective aspirations" or the imagination as a "social practice" in our contemporary era of mass mediation, migration and globalization (31-3).

Here I want to argue that already at the beginning of modern globalization in $17^{\text {th }}$ century Netherlands - before mass media and migration-we can see a new cultural imagination emerging in the form of innovative documentation of the Dutch landscape, the so-called Dutch 'realism' in landscape painting. The specific landscape perception of this 'realism' will turn out to be more culturally determined than the name might suggest. More than depicting the 'real' situation of the region or landscape around them, the early painters reflected what people were expecting or wanting to see: the painted landscape documents form an indication of early Dutch social imaginary, its identity in its cultural perception and reception of the changes in their landscape.

\section{The Rise Of The Dutch Landscape}

The Netherlands is, geologically speaking, just a speck of dust - or better, a speck of sand and mud. There is no granite bedrock, just sedimentary surface. Most of the Netherlands - literally Nederland or Low land - is three to four meters below sea level; one of the first places to disappear in the sea if nothing has been done and global climate change makes the water level rise. The Dutch dunes arose only eleven centuries ago from the North Sea. Before that time, the west coast of Holland was just a narrow neck of land: an environment of mud flats, windswept sandbars and large tongues of water. From 1000 AD large quantities of sand blew further east and formed wetlands crisscrossed by creeks and brackish swamps. 
Around the middle of the twelfth century the climate became warmer and drier, the sea level sank and people began to settle on the new land. Facing fierce storms in the early thirteenth century, they built an extensive system of dykes and sluices, and soon mastered a basic technology of land reclamation. A first colonization of the clay grounds began, and with it a dynamic process of natural, social and technical change. The new country turned out to be troublesome, waterlogged land, constantly in danger of flooding, and requiring a reliable system of collaboration, which led to the creation of water boards, the oldest democratically chosen governing bodies in the country. Furthermore, to attract peasants and laborers to this newly won territory the counts of Holland exempted them from the usual feudal duties. The result was relatively independent new communities: the population was free to travel to the towns, which turned into busy market centers, such as Alkmaar (Schama, Dutch Landscapes).

In the sixteenth century a new technology of polder formation was developed based on an innovation of windmills with rotating sails, which could take advantage of winds from all directions. Between 1561 and 1564 the first lakes were drained by these windmills, which had the strength to pump water up into ring canals. Merchants from Amsterdam provided the capital for most of these land reclamation projects, investing about ten million guilders. This was considerably more than the amount spent on the foundation of the Dutch East India Company that put the young Republic on the map as a powerful colonizing nation (de Vries, Dutch Rural Economy, 81). With thousands of merchants' ships and a well-organized international economic trade system, the Netherlands had become the leading seafaring power in the seventeenth-century: it had established trading posts and colonies spanning the world, from South Africa to the Americas to the East Indies. Amsterdam was the beating heart of this newly emerging capitalist economy, the home of the world's first stock exchange. Its wealthy merchants also invested extensively in the Dutch countryside, financing massive land reclamation projects and elaborate canal systems that guaranteed reliable time-schedules for inter-city transportation of goods. More than 400 miles of canals in a raster of straight lines and horse-drawn barges guaranteed the reliability and efficiency necessitated by the new economy (de Vries, 82).

The polder-formation was so effective that between 1590 and 1650 the land surface of northern Holland was increased by a third and about 272,000 acres of new land was added to the Dutch Republic as a whole (de Vries, Dutch Rural Economy 79-87; Making the Dutch Landscape). An early Stadsgeist or 'urban spirit' of enterprise had permeated the landscape (de Vries). Add to all this the fact that peat was the primary energy source in those days, which stripped more than 605,000 acres of land and we can imagine how in less than a century the Dutch landscape was completely transformed. By the mid-seventeenth century, Holland, the center of the European economy, had colonized not only the East 
Indies but also its own landscape. It was precisely in this period that the so-called Dutch realistic or naturalistic landscape-painting genre emerged.

\section{The Rise of Dutch Landscape Painting}

Dunes were there at the beginning, representing the birth of Dutch landscape painting. They formed a typically Dutch motif, specifically linked to the area around Haarlem, a town between Amsterdam and Alkmaar. "These areas of virgin nature," were also a favorite subject of seventeenth-century Dutch literature (Sutton, 440). Dune landscapes, with sandy paths and decaying wooden fences, were a preferred theme of early seventeenth-century painters, such as Pieter van Santvoort, Salomon van Ruysdael, Pieter de Molijn and Jan van Goyen. Interestingly, these so-called Dutch 'realists' rarely painted polders, windmills, canals, or peat digging. They clearly painted with their backs to the changes in the landscape described above. In fact, the very term "Dutch Realism" is increasingly seen as a later, nineteenth-century invention of the French Realists, who liked to promote the Dutch masters as prestigious predecessors of their own focus on non-aristocratic, anti-symbolic, everyday values.

Even though the Dutch painters were no perfect 'realists,' and did not necessarily give a topographically correct representation of the general Dutch landscape, they did bring considerable changes to the place of landscape in painting. In contrast to the Renaissance emphasis on text and interpretation, they were visually oriented and 'liberated' the Dutch landscape painting from mythical and biblical motifs. One could say, with art historian Svetlana Alpers, that they described or depicted a new kind of knowledge about the world, which is represented independently of our perception: an absence of a positioned viewer, as if the world came first, prior to our perception, and an "absence of a prior frame ... the image spread out on the pictorial surface appears to be an unbounded fragment of a world that continues beyond the canvas” (Alpers, 40).

One of the characteristic features of Dutch landscape painting is the unlimited expansion of space in all directions; there is in Peter Sutton's terms, an "unprecedented spatial and aerial unity" (Sutton, 375). Simon Schama speaks of an "undetermined open space, ... a plotless place” Schama, 69). People, animals, and things are "simply" present in the landscape as Jan van Goyen's Dune Landscape of 1631 convincingly illustrates. 


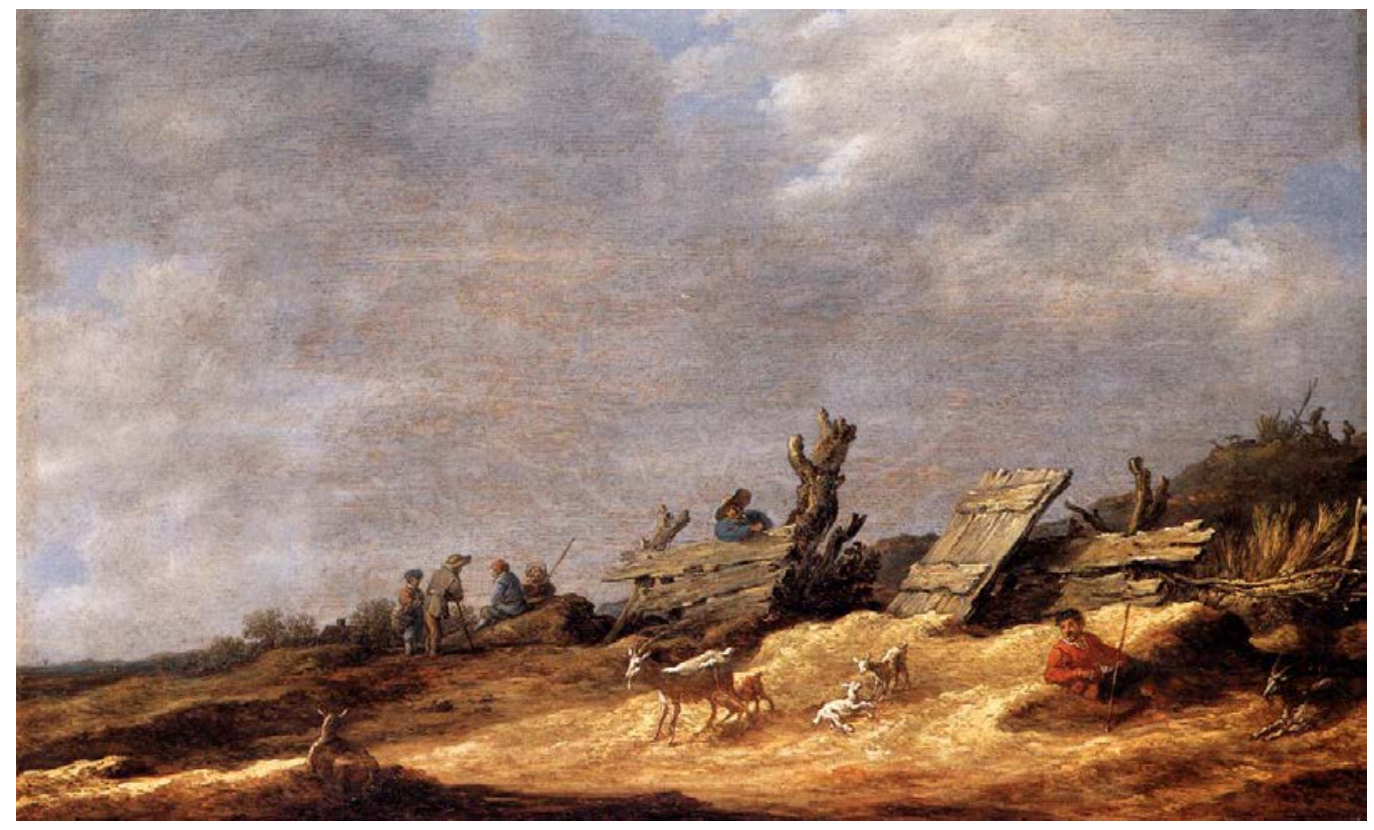

Jan van Goyen, Dune Landscape (1631). Panel of 39.5 x 62.7 cm. Herzog Anton Ulrich-Museum, Braunschweig.

As in many dune landscapes of the period, we see an old, decrepit fence, collapsing onto gnarled tree stumps. A broken door leans against a few planks and leads nowhere in particular. On the left side of the painting sits a group of four people, talking; in the center someone leans with his arm over the fence as if standing at a bar; on the right a goatherd relaxes with his back to his goats--two little ones frisk and frolic in the sun, a few older ones lie half in the shade, and in the center a nanny-goat stands still patiently, while her young kid drinks.

Dutch landscape paintings like these are indeed "plotless." There is no narrative, no allegorical or metaphysical motive. This does not mean, however, that the representation of this relatively undetermined space does not signify anything. On the contrary, as Schama mentions, it is a "highly selective and value-laden presentation of a particular kind of native habitat" (71). The landscape depicted is neither objective nor imaginary, but highly subjective. Schama interprets the "value" that is being presented as "pride of place" (71). This does not explain, however, why the dunes were such a favorite theme. Why not the new polders? They radiate an even more "plotless" expanse. Furthermore, they could add an extra dimension to the pride of the 'pride of place,' namely the fact that they were man-made. The dunes, on the other hand, depict a world independent from mankind, a place 'already there,' offering humanity a niche in an encompassing time and space stretching way beyond itself. Given the 
popularity of the dune landscape paintings, the sense of a spatiality and historicity beyond the human was clearly attractive.

In this period of newly created land, reclaimed and constructed by sheer human activity, this explicit construction of new environments apparently elicited an implicit desire to hold on to an older, familiar traditional landscape. The emergence and success of landscape painting as a genre can, in that sense, be seen as inextricably bound to the development of the polder. Facing a radical transformation of the land, the Dutch could find in the painted dune landscapes a familiarity of place. Dune landscapes are, therefore, a profoundly urban phenomenon, permeated by the spirit of the new, the spirit of the polder. They question the new, and potentially criticize the pretension to control everything: every landscape, whether polder or dune, is subject to laws of time and space that transcend mankind.

Most dune landscapes of the early $17^{\text {th }}$ century radiate a timeless atmosphere of old wagons, decrepit fences, thatched roofs in ill repair, and people who radiate a carefree calm as they lie, sit, talk or walk in this free "wild" timescaped landscape with a temporality of seasons instead of man-made structures. The "wildness" is emphasized by the suggestion of highly changeable weather: a dark threatening sky - with many shades of grey, of course - fills part of the panel, while bright sunlight illuminates another section. An atmosphere of space and time left to their own resources permeates the picture, leaving humanity as a small, not particularly significant part of larger elements.

\section{Landscape and Cultural Identity}

Landscape paintings were very popular (Chong, 104). In the mid-seventeenth century almost half of all paintings were landscapes (religious scenes, with only $13 \%$, came in second) and their distribution was remarkably democratic: people from all demographic layers bought landscapes, even burghers of modest means could own at least one small painting or print (Chong, 116). What did all those people see in these landscapes or, more significantly, as art-critic Ann Jensen Adams wonders, what did they not see (Adams, 41)?

Conspicuously absent in the story told by the dune landscapes is the busy mercantile city life as well as the fruits of this entrepreneurship: the straight-lined polders and canals. We see winding paths instead, and sandy dunes with rustic farms, or bucolic river scenes. Amidst the hustle and bustle of daily city-life the $17^{\text {th }}$ century burghers apparently preferred to let their eyes wander in the peaceful quiet of the dunes. The landscapes formed a point of rest, as Ann Jensen Adams emphasizes, a visual escape to the countryside.

Her most cogent interpretation for the popularity of the genre invokes implicitly the importance of the cultural imagination or social imaginary-communal identity that this traditional landscape affords to an increasingly 
differentiated population that sought to come to terms with a plethora of radical changes in a relatively short period of time. Besides the unprecedented economic developments, which led to the grand metamorphosis of the Dutch landscape, there was a major shift in religion from Catholicism to Protestantism after declaration of independence from Catholic Spain. All this led to an unparalleled increase in population. Wealthier, with greater religious tolerance and fewer political restrictions than other European countries, the young Republic attracted many immigrants. Between 1500 and 1650 the population of Holland tripled. The rather amorphous Regency was incapable of providing an unambiguous embodiment of sovereignty and the state did not offer a "ready body in which to invest the symbols of communal identity" (Adams, 44). This leads Adams to her interesting thesis that precisely this lack of cultural identity made the $17^{\text {th }}$ century landscape paintings so popular, suggesting that "the diversion of attention from contemporary commercial enterprises to 'natural' historical land formations and activities" created a focus for identity “formation” (57). For a people going through as many changes as the Dutch in the early $17^{\text {th }}$ century, the "visual dramatization of the landscape and its sense of history must have been reassuring" (Adams, 65). The relatively cheap, readily available dune landscapes became documents that offered a sense of place and of local history to a community that was establishing a new position and status in the international arena. The naturalizing and historisizing of the landscape helped "for the working out, not of rural issues, but of urban ones” (66).

The specific choice of dune and river landscapes is telling. The seventeenth-century landscape painters seemed uninterested in the most prominent new elements in their landscape, namely, the thousands of acres of new polders and the hundreds of miles of canals. In fact, the dune landscape can be seen as the alter ego of the polder landscape. In the dunes, time is determined by the weather, not by barge timetables of the canals; the landscape is divided by winding paths, not by documents of ownership, no one owned the dunes; anyone had access to them. Like the sky, they were democratic "space": open to all and owned by none. River-skating scenes, another favorite theme of the landscape painters, had a similarly democratic value. All levels of society mixed when skating. The frozen rivers can be seen as early versions of the boulevards of Paris or St. Petersburg where social classes mingled in public space (Berman, 212-249).

The polder builders initiated a new landscape, the landscape painters a new genre. In this new genre they created documents that celebrated dunes and rivers, in short, they had a very distinct image of what constituted Dutch landscape. The relationship between the history of the Dutch landscape and its paintings exemplifies the dynamism generated by the relation between nature and culture. Landscape is as much a cultural phenomenon as it is a natural 
phenomenon. Landscape is constantly engaged in, permeated with, political and cultural environments; a mutual engagement which results in ongoing beginnings.

The Dutch landscape painters illustrate what Simon Schama calls in his book Landscape and Memory, "a way of looking; of rediscovering what we already have, but which somehow eludes our recognition and our appreciation. Instead of being yet another explanation of what we have lost, it is an exploration of what we may yet find" (Schama, Landscape and Memory, 14). Schama gives one of his essays the telling title "Dutch Landscapes: Culture as Foreground." It is nostalgia in W. J. T. Mitchell's sense of the word: a longing-for-a-Self-that-is now-colonized - Other (Mitchell, 28). This sense of nostalgia could also be applied to our relation to the land and the development of land. Our relation to landscape often speaks a longing for the land we were familiar with, which was ours, which partly defined our sense of selves, but has been "colonized" by developments - our own, or those of others. These very developments create a new landscape which in its unfamiliarity makes us long for the one that is colonized, has lost its importance, is about to disappear, or has disappeared already.

At the highpoint of the Golden Age when extensive draining and diking projects had doubled the land area of Holland, the famous Dutch realist landscape painters did not paint what they saw around them. Their favorite theme was the diluvial dunes, not the alluvial polders. Similarly, the polders had to "season" two to three hundred years and had to have been threatened with destruction, before they caught the painterly eye.

Only in the middle and second half of the 19th century the Dutch polder landscape painting emerges as a serious genre. The Hague School of Painting (1840-1870), found inspiration in this type of Dutch landscape, with painters as Willem Roelofs, Willem Maris, and Paul Gabriel. Often called the Dutch Barbizon School, they painted polder scenes with pastures, cows, and windmills in a typically impressionist style. 


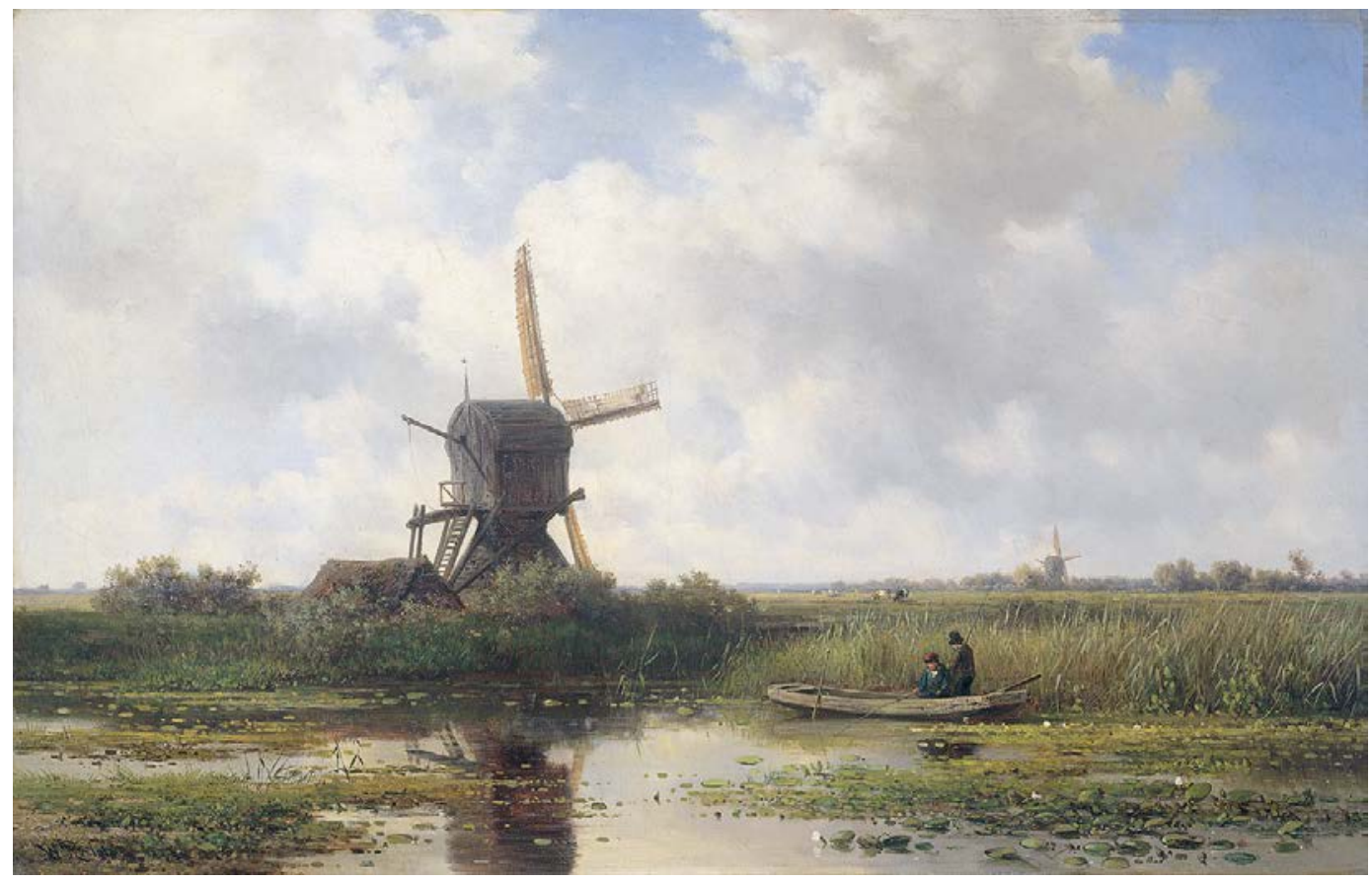

Willem Roelofs (1822-1897) In 't Gein bij Abcoude between 1870 and 1897 in Rijksmuseum Amsterdam

They reacted to the 19th century urbanization and industrialization with a typically pre- $19^{\text {th }}$ century choice of landscapes. Again, painters celebrated a landscape, which was back-grounded, if not occupied, by rather large-scale processes of change, in this case the rise of (sub-) urban and industrial developments. As their $17^{\text {th }}$ century colleagues had done, they revealed a new cultural imagination and identity formation around landscapes, most clearly expressed in the rise of a "Beauty of our country" sentiment (van Rossem).

Jac. P. Thijsse, a Dutch cultural and historical icon, schoolteacher and biologist, formulated this sentiment most famously as "our landscape" which caught the public's imagination. Around 1910, Thijsse was asked by chocolate and biscuit firm Verkade \& Co from Zaandam, a town ten kilometers north of Amsterdam, to create a new form of documentation and write a series of nature albums with added illustrations of various painters as separate little prints. With the purchase of biscuits or chocolate, people would receive a little colored picture-one piece at each purchase - to be glued into the album. It was a tremendous success.

The mix of aesthetic and educational values was a crucial impetus for popularizing the "beauty of our country" sentiment and the creation of a cultural identity around "our landscape." It helped launch the preservation movement of 
Dutch cultured landscapes: nature clubs and associations were born. It also formed a major instigation for the 1922 Amsterdam Commission of Urban Planning to adopt a regional approach in its documents of the Amsterdam Extension Plans, and to integrate the polders in the city planning. This culminated in the innovative 1932 General Extension Plan of Amsterdam, which was not just a sum of expansion plans of various neighborhoods, but-and this was a completely new document for the thirties - the center of a regional plan.

\section{Documenting Silence}

The Dutch landscape painters were the first to hint at the possible differentiation of places within places and the nesting of multiple places in the social imaginary. We might say that they were "selective realists." It is precisely this selectivity for "natural" features that forms the portal to the environmental imagination. The authenticity of the Dutch landscape lies in its natural artificiality so profoundly embedded in social political agency and cultural imagination.

The latest cultural imaginary around the Dutch tulip fields is an explicit environmental imagination: the rising awareness of their tremendous environmental costs. The wide expanse of colored bulb fields might draw many tourists, and with $80 \%$ sold on the international market, they might deliver the Dutch economy a yearly 1.2 billion Euro; however, the environmental costs are high: the amounts of pesticides to protect the bulbs against fungi, insects, and bacteria, are astounding, turning the sky and the surface water around the bulb fields into toxic zones. The Netherlands holds the world's record for agrochemicals used per hectare together with Belgium and Japan. Insecticides have caused a dramatic decline in numerous sorts of insects, bees, bumblebees, flies and dragonflies. Fewer insects likely means fewer birds, fewer frogs, less life (“Gif in de bollenstreek” Zembla, VARA Dutch television, January 8, 2011).

As I sit in the train from Amsterdam to Alkmaar, the colorful tulip fields I see out the window document a new phenomenon: they start to sound like a Silent Spring (Carson).

\section{References}

Adams, Ann Jensen. “Competing Communities in the 'Great Bog of Europe': Identity and Seventeenth-Century Dutch Landscape Painting”, in: Landscape and Power, ed. W.J.T. Mitchell (Chicago: The University of Chicago Press, 1994), 35-76.

Alpers, Svetlana. The Art of Describing, Dutch Art in the Seventeenth Century (Chicago: University of Chicago Press, 1983).

Appadurai, Arjun. Modernity at Large, Cultural Dimensions of Globalization (Minneapolis: University of Minnesota Press, 1996). 
Berlage, H.P., "Stedenbouw”, in De Beweging. Algemeen Maandschrift voor Letteren, Kunst, Wetenschap en Staatkunde 10 (1914). Quoted by Vincent van Rossem, Het Algemeen Uitbreidingsplan van Amsterdam.

Berman, Marshall. All that is Solid Melts into Air: The Experience of Modernity (London: Verso Editions, 1983).

Carson, Rachel. Silent Spring, (Boston: Houghton Mifflin Company, 2002 [1962])

Chong, Alan. "The Market for Landscape Painting in Seventeenth-Century Holland”, in: Peter C. Sutton, Masters of 17th-Century Dutch Landscape Painting.

“Gif in de bollenstreek” Zembla. VARA. 8 Jan 2011.

$<$ http://www.uitzendinggemist.nl/afleveringen/1044488-gif-in-de-bollenstreek>.

Mitchell, W.J.T. "Imperial Landscape," in Landscape and Power, ed. W.J.T. Mitchell (Chicago: The University of Chicago Press, 1994).

van Rossem, Vincent. Het Algemeen Uitbreidingsplan van Amsterdam; Geschiedenis en Ontwerp, Part II of Cornelis van Eesteren, Architect, Urbanist, ed. Manfred Bock (Rotterdam: NAi, 1993), 34-38.

Schama, Simon. "Dutch Landscapes: Culture as Foreground,” in Peter Sutton, ed., Masters of 17th-Century Dutch Landscape Painting, exhibition catalogue (Boston: Museum of Fine Arts, 1987), 64-83.

Schama, Simon. Landscape and Memory (New York: Alfred A. Knopf, 1995), 14.

Sutton, Peter C. ed., Masters of 17th-Century Dutch Landscape Painting, exhibition catalogue (Boston: Museum of Fine Arts, 1987)

de Vries, Jan. “The Dutch Rural Economy and the Landscape,” in: Christopher Brown et al., Dutch Landscape, the Early Years: Haarlem and Amsterdam, 1590-1650 (London, National Gallery, 1986), 79-87.

de Vries, Jan. "Making the Dutch Landscape and Learning to Appreciate It" a paper presented at the conference "Landscape and Technology;" January, 1997; Odense, Denmark. 